\title{
第 34 回総会ポスター賞受賞記念論文
}

総説 (推薦論文)

推薦者：日本臨床免疫学会理事, 第 34 回総会長 尾崎承一

血漿のプロテオミクス解析

苗 代 康 可 ${ }^{* 1, * 2}$, 鈴木知佐子*2, 木 村 成 寿*1, , 山本 元 久 ${ }^{* 2}$, 高 橋 裕 樹*2

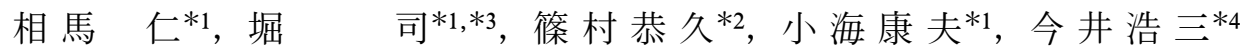

\section{—Plasma analysis of rheumatoid arthritis by SELDI-}

Yasuyoshi NAISHIRO ${ }^{* 1, * 2}$, Chisako SUZUKI ${ }^{* 2}$, Michitoshi KIMURA*1, Motohisa YAMAMOTO*2, Hiroki TAKAHASHI ${ }^{* 2}$, Hitoshi SoHmA ${ }^{* 1}$, Tsukasa HorI ${ }^{* 1,{ }^{* 3}}$ Yasuhisa SHINOMURA ${ }^{* 2}$, Yasuo KOKAI ${ }^{* 1}$ and Kohzoh IMAI ${ }^{* 4}$

${ }^{*}$ Department of Biomedical Engineering, Sapporo Medical University School of Medicine

${ }^{*}$ First Department of Internal Medicine, Sapporo Medical University School of Medicine ${ }^{*}$ Department of Pediatrics, Sapporo Medical University School of Medicine

${ }^{*} 4$ President, Sapporo Medical University School of Medicine

(Received March 23, 2007)

summary

To identify protein biomarkers linking to disease activity and treatment responses of patients with rheumatoid arthritis (RA), proteomic study using mass spectrometric analysis of plasma proteins was performed. Proteomic profiling technologies can simultaneously resolve and analyze multiple proteins in plasma. Evaluation of multiple proteins of the plasma will be essential to discover protein biomarkers. In this study, we used protein chip surface enhanced laser desorption/ionization time of flight mass spectrometry approach (SELDI-TOF MS). Through differential profiling of plasma proteins, we selected two prospective candidate biomarkers. One mass spectrometric peak distinguished patients with RA from healthy controls was transthyretin (TTR) and the other distinguished inactive patients with RA from patients with active RA was Serum Amyloid A (SAA). This study demonstrates that proteomic profiling using mass spectrometry of plasma greatly facilitates global discovery and verify clinically relevant sets of disease biomarker directly links to disease activity and treatment responses.

Key words — Rheumatoid Arthritis; Proteomics; SELDI-TOF MS; Plasma; Liposome

抄録

プロテオミクスの技術が，近年，非常に発展してきている．プロテオミクス解析は複雑な，多種類のタンパク質 混合物のプロファイルを一挙に解析することができる.さらに発現量のみではなく，タンパク質の修飾状態までも 検出可能である. とくに, 血漿のような, 多くのタンパク質を含む, 複雑なサンプルの解析に有効であると考えら れ，関節リウマチにおける診断，疾患活動性および治療効果判定に有用と思われるバイオマーカーの検索が行われ ている. 本稿では血漿のプロテオミクス解析に関する有用性, 問題点を, 関節リウマチを中心に，われわれの研究 報告を含め解説する.

\section{1. はじめに}

関節リウマチ（以下 RA）は世界人口の約 $1 \%$ と 罹患率の高い疾患であり，患者本人の QOL の低下 やそれに伴う社会的損失と社会経済にも大きな影響

\footnotetext{
*1 札幌医科大学教育研究機器センター分子機能解析部 門

$*_{2}$ 札幌医科大学内科学第一講座

*3札幌医科大学小児科学講座

*4札幌医科大学
}

を及ぼす。しかしながら，生物学的製剤が使用可能 となり，従来の治療薬では考えらないほどの画期的 な効果が得られて拈り, わが国においてもとの有効 性が証明されつつある。ただし, 年間の薬剤費が高 価であり，結核をはじめとした感染症の副作用もあ るといった問題点がある。 そこで生物学的製剤をよ り効率よく利用するためのバイオマーカーの開発が 希求されている. 今回, 我々が RA を対象に実際に 行ったマーカーの検索を例に，血漿のプロテオミク ス解析について解説する. 


\section{Proteomic analysis}

ヒトゲノムプロジェクトの終結により，すべての ヒト遺伝子が明らかになり，次の目標はすべての体 内のタンパク質を明らかにすることに移った。 mRNA 発現量の変化がそのままタンパク質の発現 量の変化と相関しない場合も多く，その機能の多く は，リン酸化，糖付加，アセチル化などの翻訳後修 飾によって司られており，実際に生体内で機能して いるのはこれらのタンパク質であるため, タンパク 質発現解析ひいてはプロテオミクス解析の重要性が 改めて認識されてきており, 近年, 目覚しく発展を 遂げている1,2)。ゲノミクスの成功により作成され た莫大な遺伝子のデータベースと近年の MS spectrometric technology の進歩により，格段に早くタ ンパク質を同定できるようになりプロテオミクス研 究の発展に拍車をかけている。しかしゲノミクスの 成功を導いた核酸を増幅する技術，すなわち PCR に相当する技術がプロテオミクスに存在しない。そ の結果, プロテオミクスの発展が試料のタンパク質 濃度と測定器の感度に限定されているといっても過 言ではない.プロテオミクスによる解析技術はいま だ発展の途中であるが，試料中に存在する異常な夕 ンパク質や，修飾されたタンパク質を直接解析する 方法として非常に優れている。また，核酸の解析と は異なり, 発現レベルの変化の解析以外にも翻訳後 修飾の変化を解析することが可能であり，さまざま な視点からタンパク質を解析することができるた め, 細胞溶解液, 血液, 涙液, 唾液, 尿, 髄液, 関 節液，乳汁といったさまざまな試料中タンパク質か ら種々のバイオマーカーの検索が行われている.

\section{3. plasma analysis}

プロテオミクスの技術により，血漿には 3000 種 類を超えるタンパク質の存在が明らかになってい る3)．血漿は，血液還流により全身諸蔵器および病 巣からのタンパク質を運搬している，血漿中には， 各組織からのタンパク質の放出があり，そのタンパ ク質のプロファイリングから健常人と疾患群間での 差異を捕らえることができる、サンプルとしての血 漿は，比較的少ない侵襲で，治療の経過に応じて繰 り返し入手できる長所もあり，バイオマーカーを探 索するためにきわめてリーズナブルであると考えら れる。しかし核酸と異なり，タンパク質は親水性や 疎水性などの化学的な性質が多様であり，含まれて

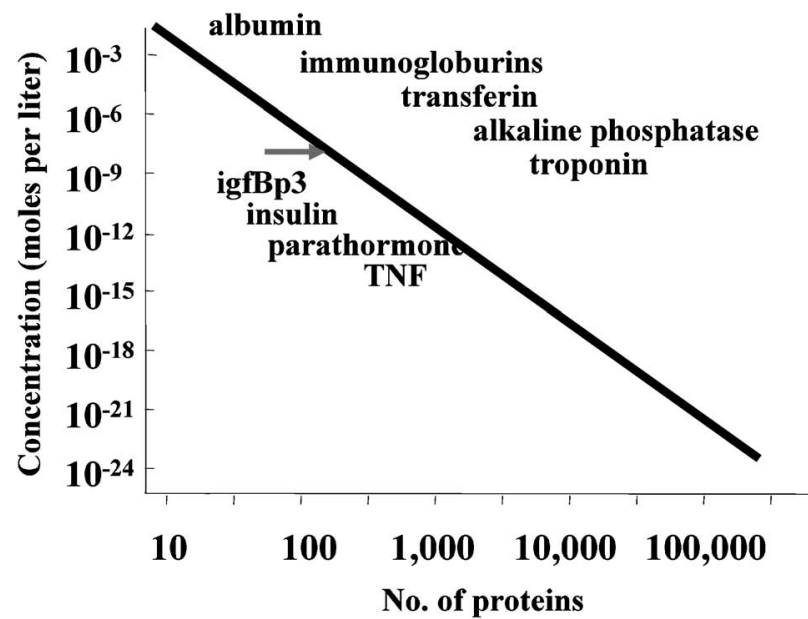

Fig. 1 血漿中に存在するタンパク質の濃度と種類 $\rightarrow$ SELDI-TOF MS による解析の検出限界を示す.

いるタンパク質のサイズも数千ダルトンから数百万 ダルトンのものまで多種多様である．さらに $10^{-10}$ $\mathrm{M}$ 末満の濃度が低いタンパク質から $10^{-6} \mathrm{M}$ 以上の

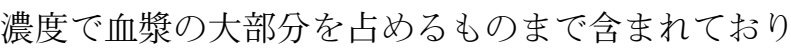
解析を困難なものにしている $(40 \mathrm{mg} / \mathrm{ml}$ の濃度で 存在しているアルブミンからわずか $1 \mathrm{ng} / \mathrm{ml}$ で存在 しているサイトカインまでさまざまである）（Fig. 1).さらにこの低濃度領域には多くの種類のタンパ ク質が存在し， $10^{-3} \sim 10^{-4} \mathrm{M}$ には数十種類のタン パク質が存在するが，さらに低濃度になればなるほ ぞ存在するタンパク質の種類は増える（Fig. 1). 以下に説明する SELDI-TOF MS の測定感度は非常 に良いとされながらも検出限界は $10^{-8} \mathrm{M}$ 程度であ り，そのままでは血漿中の 10-20\%程度のタンパク 質しか解析できず，アルブミンのような多量に存在 するタンパク質の除去, 等電点に応じた分画などの 前処理が血漿のタンパク質解析には必要になる.

\section{Plasma analysis of rheumatoid arthritis by SELDI}

われわれは surface-enhanced laser desorption / ionaization time of flight mass spectrometry（以下 SELDI-TOF MS）を利用し RA 患者のインフリキ シマブ投与前後の血漿を解析した. SELDI-TOF MS は表面化学を利用し, チップ上のタンパク質を イオン化し，質量分析器により分子量を測定する. 測定した結果を Fig. 2 に示す. 二つのピークが治 療前後抢よび健常人との比較により変化していた。

ProteinChip はタンパク質解析に適した様々な化 学的性質（陰イオン交換基, 陽イオン交換基, 逆相 
a
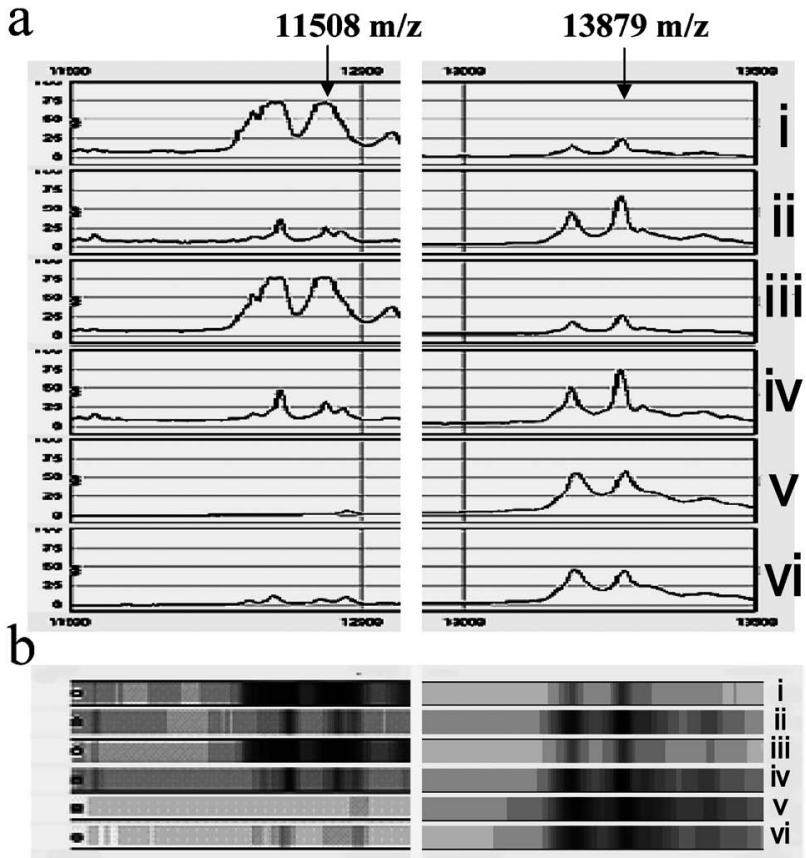

Fig. 2 SELDI-TOF MS による関節リウマチ患者および健 常人血漿の解析結果

$\mathrm{a}$ : trace image $\mathrm{b}$ : gel image

↔で示す $11508 \mathrm{~m} / \mathrm{z}$ および $13879 \mathrm{~m} / \mathrm{z}$ に変化が見られた.

i ：リウマチ患者 A 血漿治療前, ii：リウマチ患者 A 血漿治療 後, iii ：リウマチ患者 B 血漿治療前, iv：リウマチ患者 B 血 漿治療後, v : 健常人 A, vi : 健常人 B

基，順相基，金属イオン固定基，抗体，受容体タン パク，DNA）を chip 表面上に持たせてあり，その 化学的性質に親和性を持つタンパク質を特異的に補 足，濃縮することができる（Fig. 3a）。chip 表面上 に補足されたタンパク質はUV パルスレーザーを受 け，イオン化し，真空中を検知器に向かい飛行す る. 分子量の大きいものほど飛行時間は長くなり, 飛行時間から分子量が算出される（飛行時間型質量 分析）(Fig. 3b)。一度の解析で protein chip に捕捉 された複数のタンパク質の質量電荷比を同時に測定 することが可能であり, 多数のタンパク質の発現量 および質量電荷比が，ピークとして検出され，さら にゲルのイメージに変換することもできる（Fig. $2 \mathrm{~b})$ ．必要な検体はごく少量であり（p mol レべ ル), 血液, 尿, 髄液, 関節液, 沃液, 唾液, 乳汁 といった臨床検体を直接利用でき，解析に要する時 間も短く臨床への応用がしやすい利点がある.

RA 患者血漿を対象とした我々の解析の結果，そ れらのピークは serum amyloid A (SAA) と Transthyretin（TTR）であることが，アミノ酸シーケン サーによる解析にて明らかになった。SAAの SELDI に抢ける測定値は, 生化学的検査における a

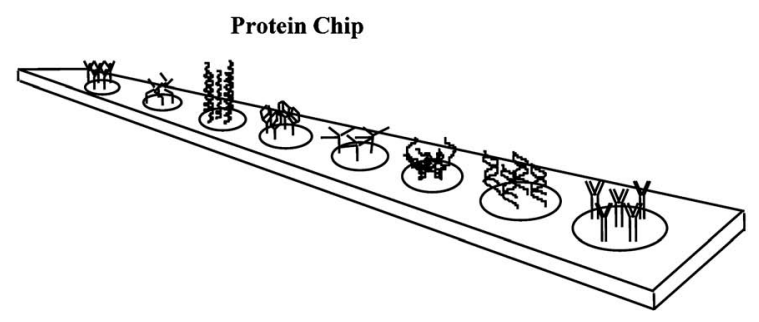

b

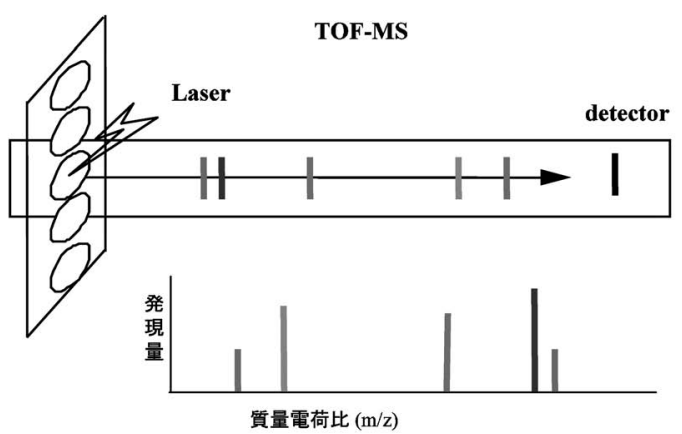

Fig. 3 protein chip 抢よびTOF MS の原理 $\mathrm{a}$ : イオン交換基, 逆, 順相基, 金属イオン固定基, 抗体, DNA 受容体タンパク, などが直径 $2 \mathrm{~mm}$ のスポットに固 定され, 親和性を持つタンパク質が濃縮, 捕捉される.

$\mathrm{b}$ : chip 表面上に補足されたタンパク質は UV パルスレー ザーを受け, イオン化し, 真空中を検知器に向かい飛行 する．小さい分子ほど detector に早く到達する.

測定值と相関し (data not shown), CRP の生化学 的検查に抢ける測定值とも相関した（Fig. 4). TTRに扔いては，SELDIによる測定のみが CRP に相関し（Fig. 3), TTR の生化学的検查に抢ける 測定值は, 治療前後で一定の傾向を示さなかった (data not shown). 今回, われわれが行った proteomicsによるRAの血漿解析において見つかった バイオマーカー候補は, 既知のタンパク質ではある が RAの状態を適切に反映しているものと考えら れ，これらのマーカーもあわせて臨床診断すること でより迅速かつ適切な疾患活動性の評価が行えるも のと考える.

SELDI-TOF MS によるバイオマーカー検索は非 常に有効と考えられ，がんなど，他の疾患領域にお いても，さかんに行われている. SELDI-TOF MS によって RA 患者血清を解析した報告としては, de Seny D にによる報告がある。彼らは，RAの biomarker 候補として5つの peak を見出し，その ひとつが MRP-8 であったと報告している4).

\section{5. 二次元電気泳動（TWO-DIMENSIONAL POLYACRYLAMIDE GEL ELECTROPHO- RESIS : 2D-PAGE)}

血漿のプロテオミクス解析に有効な手段として以 
TTR

(SELDI TOF-MS)

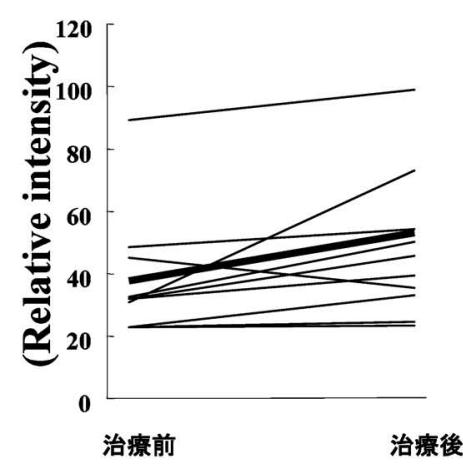

SAA (SELDI TOF-MS)
CRP(LA)

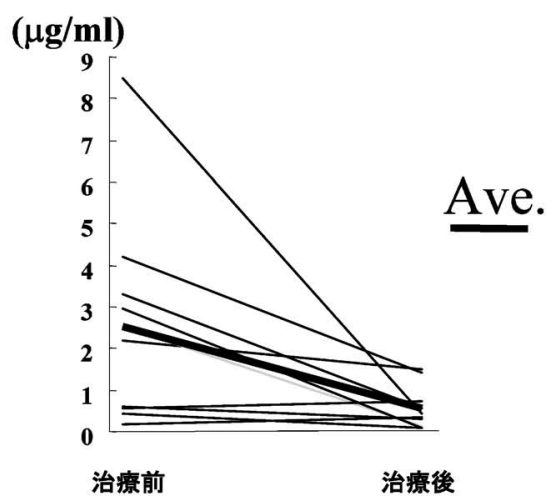

Fig. 4 関節リウマチ患者 10 名の治療前後の TTR 抢よびSAA の SELDI-TOF MS による測定值抢よび Latex Agglutination 法に よる CRP 測定值の变化

太線は平均值を示す。

前よりある技術である，原理は，タンパク質の等電 点と分子量の違いにより二次元に分離する方法であ る.この二つのパラメーターは，相関しないため翻 訳後修飾を受けたタンパク質を含め複雑な多くの種 類のタンパク質混合物も効率的に分離できる. 分離 されたタンパク質は, 銀染色やクマシーブルー染色 などによって描出され， サンプル間で比較される. 複数のゲル間に抢ける比較の際, データのばらつき や再現性に乏しいという問題を抱え, 定量的なタン パク質発現解析手段としては実用的ではないとされ ていたが，現在では同一ゲル中に多重蛍光標識した 複数のタンパク質サンプルを流すことが可能とな り，これらの問題は解決されている. 二次元電気泳 動では, 一度に数百ものタンパク質を描出すること ができ, 切り出したスポットをゲル内消化し得られ たペプチド混合物を質量分析することでタンパク質 の同定が可能である. 二次元電気泳動法により， RA のバイオマーカーを検索した報告としては,

Takeuchi らによる報告がある，彼らは，二次元電 気泳動法により, リウマチ患者血清中から, infliximab 投与前後で発現が変化する 50 もの spotを見 出し, 同定の結果, それらの中に, CRP, C3, Apo J, Apo A-I, RBP, transthyretin が含まれていたこと を報告している5 ．RAに拈いては自己抗原の検索 も盛んに行われており, Matsuo らは滑膜組織を抗 原にし二次元電気泳動法をもちいて, 患者血清中か ら自己抗体の対応抗原の検索を行っている. その結 果, シトルリン化 F-actin cappong protein alpha-1 subunit (CapZ $\alpha-1$ などの自己抗原の同定に成功し
ている6).

\section{Liposome}

われわれは，今後血漿中のタンパク質群からバイ オマーカーを検索するにあたり，いかに機能的に重 要な分子を濃縮収集してくることが重要と考え，リ ポソームをバイオプローブとして使用する方法を考 案した.リポソームは生体膜上で起こる種々の現象 をモデル的に引き起こすために作成された人工生体 膜である7). われわれは, リポソームが提供する膜 構造のタンパク質への親和性をもちいた網羅的なタ ンパク質の解析の可能性を検討し, 血漿タンパク質 の解析を通じてバイオマーカー探索への応用の可能 性を検討した ${ }^{8)}$ (Fig. 5). 本法では $\mathrm{Ca}^{2+}$ 依存的に リポソームに結合するタンパク質群を濃縮収集する 方法である、 $\mathrm{Ca}^{2+}$ は神経伝達物質の分泌に大きく 関わり細胞の分化, 増殖などの重要な因子である. しかし種々の病態で認められる持続的な $\mathrm{Ca}^{2+}$ 濃度 の上昇は酵素等の異常活性化により細胞障害を引き 起こしうる. 関節リウマチで特異的に出現する抗 CCP 抗体の対応抗原にシトルリン化タンパク質が あるが，このシトルリン化を引き起こすぺプチジル アルギニン・デイミナーゼ (PAD) は $\mathrm{Ca}^{2+}$ による 活性化機構が明らかになっている. 障害された細 胞が何らかのタンパク質分泌を起こす可能性があ り，そのタンパク質の中に血液中にまで運ばれるも のが存在すれば, 病態マーカーとなりうる ${ }^{10)}$. 血液 中には約 $2 \mathrm{mM}$ の高い $\mathrm{Ca}^{2+}$ が存在しているため, リポタンパク質や細胞膜と結合している可能性があ 


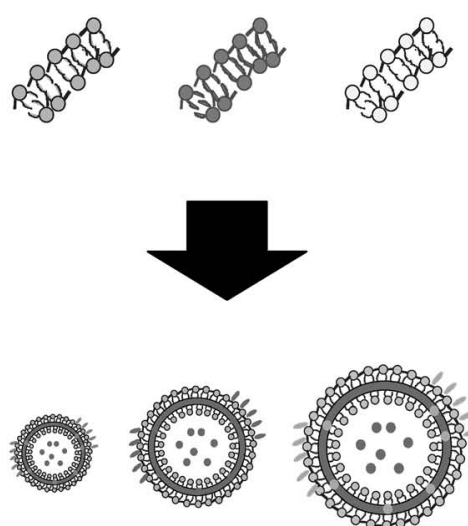

リポソームの作製

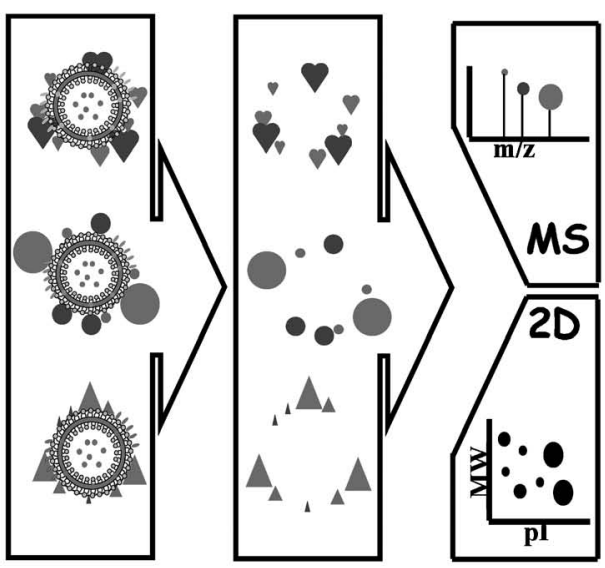

リポソーム結合タンパク質の定量分析

Fig. 5 リポソームによるバイオマーカー検索の strategy 模式図

リポソームの作製：リン脂質（egg PC ; Phosphatidyl Choline, PS ; Phosphatidyl Serine) はクロロホルム/メタノール (2: 1) に溶解し $(10 \mathrm{mg} / \mathrm{ml})$, 必要量の PC と PS を 9: 1 に混ぜ, $\mathrm{N}_{2}$ (gas) で乾固. 細胞膜に存在する酸性リン脂質 (PS) の含量が約 $10 \%$ であり，リポソームの組成は $10 \% \mathrm{PS}$ と残りは主要な中性脂質であるPCとした.

リポソーム結合タンパク質の定量分析 : 定量分析の手段として SELDI-TOF MS のほか二次元電気泳動等の解析方法が利用で きる
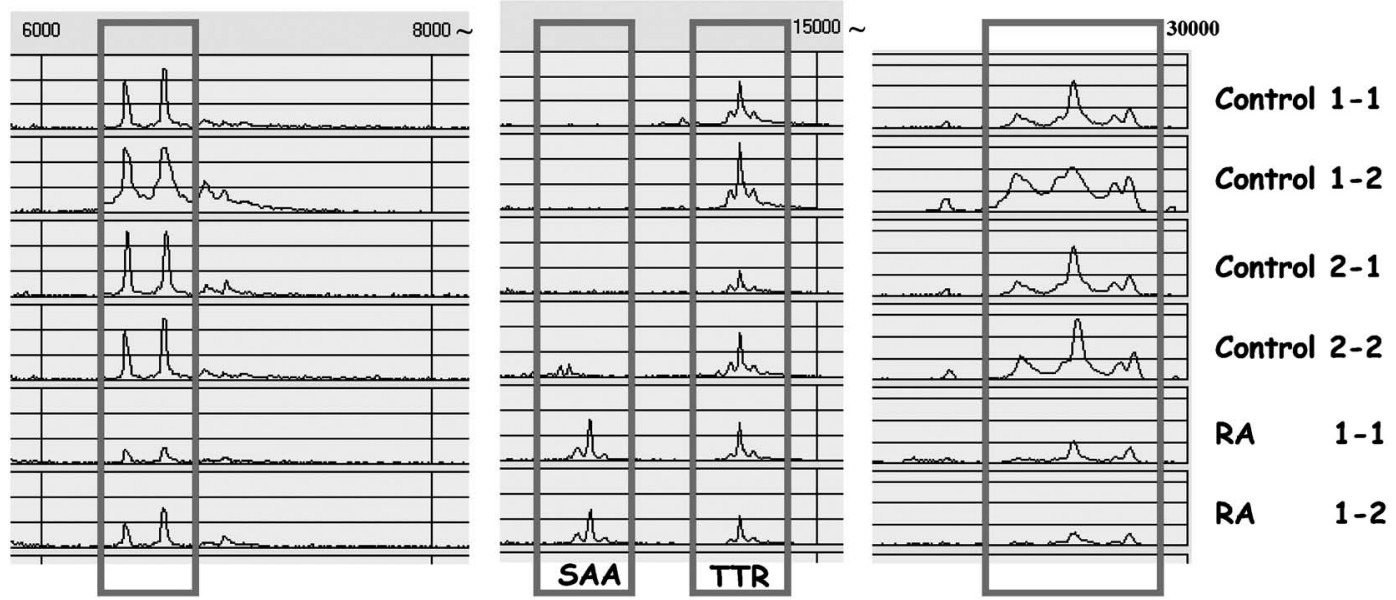

Fig. 6 リポソーム結合タンパク質の SELDI-TOF MS による解析

健常人二名とリウマチ患者治療前一名の血漿からリポソーム結合タンパク質を分離し，SELDI-TOF MSにより解析した. (duplicate)

る.われわれは, $\mathrm{Ca}^{2+}$ 依存的にリン脂質と相互作 用する血漿タンパク質に注目し，実際にRA 患者血 漿中の $\mathrm{Ca}^{2+}$ 依存的 Liposome 結合タンパク質を SELDI-TOF MS により解析した結果（Fig. 6)，上 記の SAA, TTR のほかにも, 健常人と比して発現 が増加している peak の存在が明らかになり，現在 同定中である.

7. おわりに

血漿のプロテオミクス解析についてわれわれの研 究結果も交え述べた。血漿中にはいまだ解析されて いない未知の低濃度領域が存在し，質量分析技術の
発展は道の領域の解析を可能にしようとしている. 今後プロテオミクスがさらに発展し新たな診断マー カーや治療標的分子の同定がなされることが期待さ れる。

\section{文献}

1) Griffin, T. J., et al. : Complementary profiling of gene expression at the transcriptome and proteome levels in Saccharomyces cerevisiae. Mol Cell Proteomics, 1 : 323-333, 2002.

2) Chen, G., et al. : Discordant protein and mRNA expression in lung adenocarcinomas. 
Mol Cell Proteomics, 1 : 304-313, 2002.

3) Omenn GS, et al. : Overview of the HUPO Plasma Proteome Project : results from the pilot phase with 35 collaborating laboratories and multiple analytical groups, generating a core dataset of 3020 proteins and a publicly-available database. Proteomics. 5(13) : 3226-3245, 2005.

4) de Seny D, et al. : Discovery of new rheumatoid arthritis biomarkers using the surface-enhanced laser desorption/ionization time-of-flight mass spectrometry ProteinChip approach. Arthritis Rheum. 52(12) : 3801-3812, 2005.

5) Takeuchi $T$, et al. : Serum protein profile of rheumatoid arthritis treated with anti-TNF therapy (infliximab). J Chromatogr B Analyt Technol Biomed Life Sci. Feb 24, 2007.
6) Matsuo K, et al. : Identification of novel citrullinated autoantigens of synovium in rheumatoid arthritis using a proteomic approach. Arthritis Res Ther. 8(6) : R175, 2006.

7) Torchilin, V.P, et al. :, Oxford University Press, Preparation of liposomes in Liposomes, second edition, A practical approach, pp3-29, 2003.

8）木村成寿，ほか：リポソームをリガンドとし て用いた血漿蛋白質のプロテオミクス解析. 生物物理化学 50:231-236, 2006.

9) Arita K, et al. : Structural basis for $\mathrm{Ca}(2+)$ induced activation of human PAD4. Nat Struct Mol Biol. 11 (8) : 777-783, 2004.

10) Trump BF, Berezesky IK. Calcium-mediated cell injury and cell death. FASEB J.9(2) : 219228, 1995. 